\begin{tabular}{|c|c|c|}
\hline \multicolumn{3}{|c|}{ Jurnal Warna : Jurnal Pendidikan Dan Pembelajaran Anak Usia dini. } \\
& Maret 2020. Vol 05. No. 01 \\
\hline Received: Februari 2020 & Accepted: Februari 2020 & Published: Maret 2020 \\
\hline & Article DOI: $10.24903 / j w . v 5 i 2.421$ \\
\hline
\end{tabular}

\title{
PENGENALAN SAINS PADA ANAK USIA DINI DI PAUD TERPADU SHABWA AMANAH LANDASAN ULIN UTARA KEC. LIANG ANGGANG KOTA BANJARBARU
}

\author{
Ratu Noor Khalidah \\ Pendidikan Islam Anak Usia Dini UIN Antasari Banjarmasin \\ ratunoorkhalidah29@gmail.com \\ Nor Izzatil Hasanah \\ Pendidikan Islam Anak Usia Dini UIN Antasari Banjarmasin \\ izhanorhasanah@gmail.com
}

\begin{abstract}
Abstrak
Penelitian ini bertujuan untuk mengetahui Pengantar Ilmu Pengetahuan pada Anak Usia Dini dalam Pendidikan Anak Usia Dini TK Shabwa Amanah Ulin, Liang Anggang, Banjarbaru. Subjek dalam penelitian ini adalah 1 guru pengantar sains dan anak kelompok A terdiri dari 12 anak. Analisis data dalam penelitian ini menggunakan Milles dan Huberman yang dilakukan secara interaktif menggunakan data yang terdiri dari reduksi, penyajian data, dan penarikan kesimpulan (coding). Berdasarkan hasil penelitian ini menunjukkan bahwa pengenalan sains pada anak usia dini di TK Shabwa Amanah Ulin, Liang Anggang, Banjarbaru dengan memperkenalkan konsep sains berupa pencampuran air dengan sabun menjadi gelembung kecil, tenggelam dan mengambang, berwarna perubahan dan penyerapan air menggunakan 1) Metode demonstrasi, metode eksperimental, metode percakapan (tanya jawab), metode penugasan, metode bermain, dan metode bernyanyi. 2.) media yang digunakan adalah media visual dalam bentuk media realia dan media audio-visual menggunakan laptop dan speaker 3.) Penilaian yang diberikan adalah dalam bentuk menugaskan permainan kepada anak-anak, mengamati penilaian, mengevaluasi melalui percakapan, serta produk anak-anak.
\end{abstract}

Kata kunci : Pengantar, Sains, Anak Usia Dini

\section{Abstract}

This study aims to determine the Introduction to Science in Early Childhood in Early Childhood Education Shabwa Amanah kindergarten of Ulin, Liang Anggang, Banjarbaru. The subjects in this study were 1 science introduction teacher and A group children consist 12 children. The data analysis in this research used Milles and Huberman which was conducted interactively using data consisting of reductions, presenting data, and conclusion (coding).

Based on the results of this study indicate that the introduction of science in early childhood in Shabwa Amanah kindergarten of Ulin, Liang Anggang, Banjarbaru with introduces the concept of science in the form of mixing water with soap into small bubbles, sinking and floating, color changes and water absorption using 1) Demonstration method, the experimental method, the conversation method (question and answer), the assignment method, the play method, and the singing method. 2.) the media used are visual media in the form of realia media and audio-visual media using laptops and speakers 3.) The assessment given is in the form of assigning games to children, observing assessments, evaluating through conversation, as well as the children products .

Keywords. Introduction, Science, Early Childhood 


\begin{tabular}{|c|c|c|}
\hline \multicolumn{3}{|c|}{ Jurnal Warna : Jurnal Pendidikan Dan Pembelajaran Anak Usia dini. } \\
& Maret 2020. Vol 05. No. 01 \\
\hline Received: Februari 2020 & Accepted: Februari 2020 & Published: Maret 2020 \\
\hline & Article DOI: $10.24903 / j w . v 5 i 2.421$ \\
\hline
\end{tabular}

\section{PENDAHULUAN}

Anak usia dini atau (AUD) adalah anak yang memiliki usia nol hingga enam tahun yang mempunyai sifat unik dikarenakan dalam proses tumbuh dan berkembang anak berbeda-beda (Anik Lestariningrum, 2017:1). Anak memerlukan pendidikan yaitu Pendidikan Anak Usia Dini atau disebut (PAUD). PAUD merupakan penyelenggaraan pendidikan yang memberikan anak pembinaan melalui rangsangan untuk mengembangkan semua aspek perkembangan (Meiti H. Idris, 2015:17).

Dalam Peraturan Pemerintah Tahun 2014 No 137 tentang Standar PAUD, pada aspek pengembangan kognitif (kecerdasan) terdapat 3 hal pokok yaitu belajar memecah masalah, berpikir simbolik dan berpikir logis seperti mengenal konsep sederhana. Sehingga kemajuan aspek perkembangan kognitif untuk AUD berhubungan dengan pengetahuan alam (sains). Dalam Al-Qur'an sudah tertulis sebagaimana firman Allah Swt yang berhubungan dengan pengetahuan alam (sains) (QS.Al-Baqarah (2) Ayat 164):

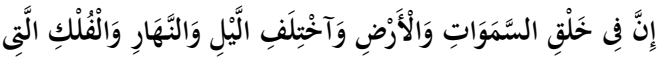

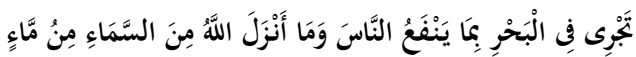

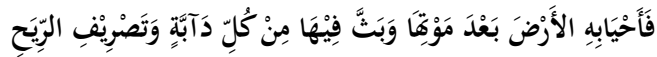

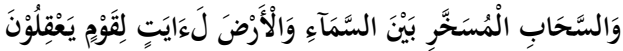

$$
\begin{aligned}
& \text { Dalam kurikulum dikatakan bahwa }
\end{aligned}
$$
pengenalan sains pada anak dapat membantu meningkatkan semua aspek perkembangan anak melalui ilmu pengetahuan dan melatih kemampuan berpikir anak. Sains untuk anak adalah pembelajaran tentang alam yang ada dalam kehidupan, Sains juga dapat melatih kemampuan berpikir serta daya ingat atau bisa disebut dengan perkembangan aspek kognitif (kecerdasan) karena pada perkembangan aspek kognitif (kecerdasan) anak dapat belajar untuk mendapatkan solusi atau untuk memecahkan masalah yang dihadapinya (Budiyanti, 2007).

Berdasarkan hasil observasi yang telah peneliti lakukan pada tanggal 9 November 2018 kebeberapa PAUD/TK di Landasan Ulin, pengenalan sains tidak banyak dikenalkan pada anak usia dini, dari beberapa PAUD /TK yang telah penulis teliti ada sedikit PAUD yang mengenalkan pengenalan sains pada anak usia dini itu juga pengenalannya dengan metode yang biasa serta menggunakan lembar kerja anak, dan ada satu PAUD yang ingin penulis teliti yaitu di PAUD Terpadu Shabwa Amanah Landasan Ulin Utara Kec. Liang Anggang Kota Banjarbaru, karena di PAUD ini mengenalkan sains pada anak usia dini dengan metode yang menarik, sehingga menjadikan peneliti tertarik memilih sekolah PAUD Tersebut dan meneliti tentang Pengenalan Sains untuk Anak Usia Dini di PAUD Terpadu Shabwa Amanah Landasan Ulin Utara Kec. Liang Anggang Kota Banjarbaru. 


\begin{tabular}{|c|c|c|}
\hline \multicolumn{3}{|c|}{ Jurnal Warna : Jurnal Pendidikan Dan Pembelajaran Anak Usia dini. } \\
Maret 2020. Vol 05. No. 01 \\
\hline Received: Februari 2020 & Accepted: Februari 2020 & Published: Maret 2020 \\
\hline & Article DOI: $10.24903 / j w . v 5 i 2.421$ \\
\hline
\end{tabular}

Fokus Penelitian penelitian ini tentang Pengenalan Sains pada Anak Usia dan Tujuan Penelitian adalah bertujuan untuk mengetahui Pengenalan Sains pada Anak Usia Dini di PAUD Terpadu Shabwa Amanah Landasan Ulin Utara Kec. Liang Anggang Kota Banjarbaru.

Penelitian ini sejalan dengan yang dilakukan oleh Neni Susilowati, (2016) dengan judul: tentang Pengenalan Sains Pada Anak Kelompok B Melewati Percobaan Sederhana Dalam Pembelajaran Sains (Studi Kasus Di KB-RA IT Al-Husna Yogyakarta). Hasil yang didapat menunjukkan: a. topik percobaan sains b. Benda atau media c. Metode Eksperimen, demonstrasi, dicovery dan inquiry, field trip dan kunjungan. $d$. berperan guru sebagai perencana, fasilitator, observer, motivator, organisator, model, evaluator, dan teman eksplorasi anak. f. Hasil kegiatan percobaan berupa pemahaman fakta atau konsep. g. Proses pengenalan sains melalui pelaksanaan percobaan dan evaluasi, dengan kegiatan percobaan sederhana. Penelitian lain juga yang pernah dilakukan oleh Irma Yanti Siregar (2019) dengan judul: Penerapan Metode Eksperimen Dalam Pembelajaran Sains Untuk Anak Usia Dini Di Tk Siti Al-Hasan Kecamatan Batang Kuis Kabupaten Deli Serdang. Hasil penelitian ini mengungkapkan tiga temuan yaitu 1). Tahap persiapan metode eksperimen 2). Penerapan metode eksperimen 3). Tahap evaluasi metode eksperimen dalam pembelajaran sains. Kemudian penelitian yang dilakukan oleh Nita Ratna Sari, (2015) dengan judul: Metode Eksperimen Berpengaruh Terhadap Kemampuan Sains Anak. Hasil yang di dapat bahwa metode eksperimen berpengaruh pada anak kelompok B TK Pertiwi Sribit Kecamatan Delanggu terhadap kemampuan sains.

Penelitian ini diharapkan memberi manfaat untuk bahan kajian lebih lanjut dan dapat dijadikan referensi mengenai pengenalan sains pada AUD. Sebagai bahan penunjang dan masukan untuk memajukan kualitas pendidikan. Untuk menambah koleksi penelitain ilmiah, khususnya berkaitan dengan pengenalan sains pada anak usia dini. Sebagai masukan untuk lembaga agar bisa mengenalkan sains pada anak usia dini. Agar meningkatkan kualitas pembelajaran dalam melaksankan kegiatan belajar mengajar.Untuk Memberikan kemudahan dan kesenangan dalam meningkatkan pengenalan sains dan diharapkan menambah wawasan dan ilmu pengetahuan.

\section{METODE PENELITIAN}

Rancangan penelitian ini menggunakan pendekatan Kualitatif Jenis dalam penelitian yang digunakan dalam penelitian ini adalah penelitian lapangan (Field Research)

Subjek dalam penelitian ini adalah anak kelompok A berjumlah 12 orang dan 1 


\begin{tabular}{|c|c|c|}
\hline \multicolumn{3}{|c|}{ Jurnal Warna : Jurnal Pendidikan Dan Pembelajaran Anak Usia dini. } \\
& Maret 2020. Vol 05. No. 01 \\
\hline Received: Februari 2020 & Accepted: Februari 2020 & Published: Maret 2020 \\
\hline & Article DOI: $10.24903 / j w . v 5 i 2.421$ \\
\hline
\end{tabular}

guru yang mengajarkan pengenalan sains. Objek yang diteliti dalam penelitian ini adalah Pengenalan Sains untuk Anak Usia Dini di PAUD Terpadu Shabwa Amanah Landasan Ulin Utara Kec. Liang Anggang Kota Banjarbaru. Informan dalam penelitian ini adalah kepala sekolah. Lokasi penelitian Landasan Ulin Utara Kec. Liang Anggang Kota Banjarbaru. Lama penelitian selama dua bulan.

$$
\text { Teknik pengumpulan data }
$$
mengguanakan Observasi (Pengamatan) untuk melihat bagaimana pengenalan sains pada anak usia dini di PAUD Terpadu Shabwa Amanah Landasan Ulin Utara Kec. Liang Anggang Kota Banjarbaru, Wawancara/Interview untuk mendapat informasi tentang pengenalan sains pada anak usia dini di PAUD Terpadu Shabwa Amanah Landasan Ulin Utara Kec. Liang Anggang Kota Banjarbaru dan dokumentasi digunakan untuk mendapatkan dokumen-dokumen pendukung.

Teknik analisis data yang dipakai adalah model Miles dan Hubermen, Langkah-langkah analisis data kualitatif dalam model Miles dan Hubermen yaitu: Tahap pengumpulan data, tahap reduksi data, display data terakhir verifikasi dan Menarik Kesimpulan.

Pengecekan keabsahan data yaitu perpanjangan pengamatan, ketekunan pengamatan, tringulasi.

\section{HASIL DAN PEMBAHASAN \\ HASIL}

Penyajian data yang dipaparkan dalam penelitian ini berupa deskripsi data yang akan disajikan untuk menggambarkan keadaan data dalam bentuk uraian atau kalimat mengenai Pengenalan Sains Pada Anak Usia Dini di PAUD Terpadu Shabwa Amanah Landasan Ulin Utara Kec. Liang Anggang Kota Banjarbaru yang meliputi metode, media dan peneilaian. Metode yang dipergunakan yaitu metode demontrasi, metode eksperimen, metode bercakap-cakap (tanya jawab), metode pemberian tugas, metode bermain, dan metode bernyanyi. Media yang digunakan adalah media visual berupa media realia dan media audio visual. Penilain yang digunakan adalah penilaian observasi dimana guru memperhatikan apa saja permainan yang dimainkan anak-anak, penilaian pemberikan penugasan permainan pada anak, penilaian melalui percakapan, serta hasil karya.

\section{PEMBAHASAN}

Pembahasan dalam penelitian ini membahas tentang hasil berdasarkan data lapangan yang diangkat sehingga dapat diketahui tingkat keberhasilan apakah hasil sudah sesuai dengan yang diharapkan sehingga permasalahan terpecahkan untuk mengetahui bagaimana pengenalan sains pada anak usia dini di PAUD Terpadu Shabwa Amanah Landasan Ulin Utara Kec. 


\begin{tabular}{|c|c|c|}
\hline \multicolumn{3}{|c|}{ Jurnal Warna : Jurnal Pendidikan Dan Pembelajaran Anak Usia dini. } \\
& Maret 2020. Vol 05. No. 01 \\
\hline Received: Februari 2020 & Accepted: Februari 2020 & Published: Maret 2020 \\
\hline & Article DOI: $10.24903 / j w . v 5 i 2.421$ \\
\hline
\end{tabular}

Liang Anggang Kota Banjarbaru. sebagai berikut:

1. Metode pengenalan sains di PAUD Terpadu Shabwa Amanah Landasan Ulin Utara Kec. Liang Anggang Kota Banjarbaru yang digunakan selama pengenalan sains yaitu menggunakan metode:

Pengenalan sains pada anak usia dini khusunya disekolah PAUD Terpadu Shabwa Amanah Landasan Ulin Utara Kec. Liang Anggang Kota Banjarbaru menggunakan metode: a. Metode eksperimen, Dalam pembelajaran pengenalan sains salah satu metode yang digunakan guru dalam mengenalkan sains pada anak usia dini adalah dengan menggunakan metode eksperimen, karena dengan metode eksperimen anak diberikan pengalaman yang nyata dan anak dapat mengamati hasil percobaan yang ia buat sendiri secara langsung. Dalam menggunakan metode eksperimen juga lebih seru karena anak-anak bermain menggunakan bahan atau alat-alat yang mungkin tidak semua dikenalnya sehingga membuat anak dapat mengenal lebih banyak tentang bahan atau alat-alat yang akan dipakainya dalam pembelajaran pengenalan sains. Seperti yang peneliti lihat bahwa ada beberapa permainan menggunakan metode eskperimen yang telah dikenalkan seperti membuat belalai gajah, percobaan membedaan jeruk yang sudah dikupas dan yang belum dikupas lalu dimasukkan kedalam air, tisu warna berjalan, serta bunga mekar diatas air. Dengan adanya metode ini guru dapat memberikan anak pengalaman yang nyata serta anak dapat mengamati secara langsung hasil percobaan yang ia buat sendiri. Sebagaimana yang dikemukakan oleh Anik Lestariningrum tentang metode eksperimen, yang mana, metode eskperimen merupakan metode dalam pengenalan sains yang memberikan pengalaman-pe ngalaman yang nyata yang diberikan oleh guru kepada anak dengan cara anak mengamati hasil secara langsung setelah melakukan percobaanpercobaan sederhana disebut dengan metode eksperimen. (Anik Lestariningrum, 2017:58). Adapun langkah-langkah dalam pelaksanaan pembelajaran melalui metode eksperimen yaitu: 1). Menetapkan tujuan eksperimen, adapun tujuan eksperimen adalah untuk meningkatkan aspek perkembangan anak. 2). Mempersiapkan alat dan bahan yang diperlukan, adapun alat dan bahan dalam kegiatan ini adalah air, pewarna, sabun, botol, anduk kecil dll. 3). Menyiapkan tempat pelaksanaan eksperimen. 4). Perhatikan keamanan dan kesehatan agar dapat mengahindari resik 5). Perhatikan tata tertib atau disiplin, terutama dalam menjaga perlatan dan bahan yang akan digunakan serta mengalokasikan waktu. 


\begin{tabular}{|c|c|c|}
\hline \multicolumn{3}{|c|}{ Jurnal Warna : Jurnal Pendidikan Dan Pembelajaran Anak Usia dini. } \\
& Maret 2020. Vol 05. No. 01 \\
\hline Received: Februari 2020 & Accepted: Februari 2020 & Published: Maret 2020 \\
\hline & Article DOI: $10.24903 / j w . v 5 i 2.421$ \\
\hline
\end{tabular}

Berikan penjelasan tentang apa yang harus diperhatikan dan tahapan yang harus dilakukan oleh anak. Sebelum pelaksanaan eksperimen, guru memberikan prosedur yang harus diperhatikan dalam metode eksperimen. (Irma Yanti Siregar, 2019:12). Langkah langkah diatas sesuai dengan langkah yang dilakukan ibu Husnul sebelum kegiatan sains seperti menetapkan tujuan eksperimen, mempersiapkan alat dan bahan yang diperlukan, adapun alat dan bahan dalam kegiatan ini adalah air, pewarna, sabun, botol, anduk kecil dll. Menyiapkan tempat pelaksanaan, memperhatikan keamanan dan kesehatan, memperhatikan tata tertib atau disiplin, terutama dalam menjaga perlatan dan bahan yang digunakan serta mengalokasikan waktu. Berikan penjelasan tentang sebelum pelaksanaan eksperimen, guru memberikan prosedur yang harus diperhatikan dalam metode eksperimen. b. Metode bermain dunia anak adalah dunia bermain sehingga diperukannya metode bermain untuk anak usia dini. Dengan metode bermain pembelajaran pengenalan sains menjadi lebih seru, walaupun hanya dengan bermain sebenarnya anak telah menemukan pembelajaran karena melalui aktivitas bermain anak juga telah melakukan aktivitas belajar yang menyenangkan. Metode bermain dalam pengenalan sains di PAUD PAUD Terpadu Shabwa Amanah Landasan Ulin Utara Kec. Liang Anggang Kota Banjarbaru terdapat dalam kegiatan sentra karena didalam sentra bahan alam banyak permainan yang dapat diajarkan, seperti anak bermain kolase, bermain memasukkan biji buah jeruk dan lain sebagainya. Hal ini sejalan dengan sebagaimana yang dikemukakan oleh Frobel menyimpulkan bahwa pendidikan anak adalah lewat bermain. Selain itu juga Bruner mengemukakan bahwa bermain memotivasi anak untuk melakukan berbagai kegiatan dalam menyelesaikan berbagai permasalahan melalui penemuannya sendiri (Dwi Yulianti, 2010:31-32). c. Metode bercakap-cakap dalam penyampaian materi pengenalan sains metode bercakap-cakap merupakan salah satu metode yang paling diperlukan, karena dengan bercakap-cakap guru dan anak akan sama-sama mendapatkan informasi. Anak- anak akan bertanya jika guru memperlihatkan hal baru yang anak tidak kenal dan ia akan selalu bertanya ataupun menceritakan apa yang ia ketahui keguru ataupun terutama teman-temannya . Anak sangat suka bertanya seperti apa warna pelangi, apa rasa buah apa warna buah dan lain sebagainya dalam metode bercakap-cakap tidak hanya anak yang aktif dalam tapi guru juga harus aktif dalam bercakap-cakap . Hal ini sejalan 


\begin{tabular}{|c|c|c|}
\hline \multicolumn{3}{|c|}{ Jurnal Warna : Jurnal Pendidikan Dan Pembelajaran Anak Usia dini. } \\
& Maret 2020. Vol 05. No. 01 \\
\hline Received: Februari 2020 & Accepted: Februari 2020 & Published: Maret 2020 \\
\hline & Article DOI: $10.24903 / j w . v 5 i 2.421$ \\
\hline
\end{tabular}

dengan sebagaimana yang dikemukakan oleh Dwi Yulianti tentang pengertin metode bercakap-cakap merupakan salah satu cara berkomunikasi dengan orang lain. Metode bercakap-cakap merupakan cara untuk menyampaikan pelajaran yang diajarkan melalui bercakap-cakap dalam bentuk tanya jawab antara anak dengan guru atau anak dengan anak. Metode ini bermanfaat untuk menambah keberanian anak dalam menunjukkan perasaan, keinginan, kebutuhan secara lisan dan juga memperoleh pengetahuan dan wawasan (Dwi Yulianti, 2010:36-37). d. Metode demonstrasi merupakan metode yang digunakan guru untuk menjelaskan pembelajaran kepada anak. Metode demontrasi ini bermanfaat untuk memberikan atau menjelaskan tentang suatu kejadian. Dengan menggunakan metode demontrasi guru dapat meningkatkan pemahaman anak karena anak dapat dipinta untuk memperhatikan serta mendengarkaan apa yang disampaikan oleh guru. seperti halnya guru menjelaskan atau sambil mengajarkan kepada anak bagaimana cara memainkan permainan seperti belalai gajah sehingga seorang guru harus memberi contoh terlebih dahulu. baik dari bagaimana membuat belalai gajah dan meniup balon dan lain sebaginya. Hal ini sejalan dengan sebagaimana yang dikemukakan oleh Dwi Yulianti tentang metode demontrasi yang mana metode ini merupakan cara untuk menunjukkan dan mengajarkan cara-cara mengerjakan sesuatu. Metode ini bermanfaat untuk memberikan gambaran dalam menjelaskan suatu kejadian atau peristiwa kepada anak. Dengan metode demonstrasi, guru dapat meningkatkan pemahaman melalui penglihatan dan pendengaran. Anak bisa diminta untuk memperhatikan dan mendengarkan dengan baik semua penjelasan guru sehingga anak lebih paham tentang cara mengerjakan sesuatu. Dengan demikian selanjutnya anak dapat meniru cara melakukan kegiatan yang dilakukan oleh guru (Dwi Yulianti, 2010:38). e. Metode pemberian tugas seperti yang dilakukan di PAUD ini adalah dengan meminta anak bermain apa yang ia mau dan meminta anak menyelesaikan kegiatan sampai selesai, seperti anak memainkan permainan kolase buah jeruk anak harus menyelesaikan tugas tersebut barulah bisa bermain kepermainan selanjutnya. Hal ini sejalan dengan sebagaimana yang dikemukakan oleh Dwi Yulianti tentang metode pemberian tugas merupakan cara pemberian pengalaman belajar dengan memberikan pengalaman secara sengaja diberikan kepada anak. Manfaat dari metode ini adalah untuk meningkatkan cara belajar yang lebih baik dan memantapkan penguasaan perolehan hasil 


\begin{tabular}{|c|c|c|}
\hline \multicolumn{3}{|c|}{ Jurnal Warna : Jurnal Pendidikan Dan Pembelajaran Anak Usia dini. } \\
& Maret 2020. Vol 05. No. 01 \\
\hline Received: Februari 2020 & Accepted: Februari 2020 & Published: Maret 2020 \\
\hline & Article DOI: $10.24903 / j w . v 5 i 2.421$ \\
\hline
\end{tabular}

belajar (Dwi Yulianti, 2010:39). f. Metode nyanyian dan lagu merupakan metode yang digunakan oleh guru dalam pengenalan sains karena dengan nyanyian dan lagu anak akan lebih mudah mengingat terutama dalam mengingat kosakata dalam pengenalan sains seperti pada lagu

"Tema pelangi"

Ada warna pelangi

Pelangi. . . pelangi ... .

Me Ji Ku Hi Bi Ni U

Itu singkatannya

Merah

Jingga

Kuning

Hijau

Biru

Nila

Ungu

Me Ji Ku Hi Bi Ni U

kan ku ingat selalu

Lagu berkaitan dengan materi yang akan dikenalkan dalam pengenalan sainns sebagaimana yang dikemukakan Sri Ekonomi bahwa metode pembelajaran dengan menggunakan nyanyian / lagu adalah salah satu metode atau cara mengajar (M.F Sri Ekonomi, 2007 :94).

2. Media Pengenalan Sains di PAUD Terpadu Shabwa Amanah Landasan Ulin Utara Kec. Liang Anggang Kota Banjarbaru.
Guru juga membuat dan menyediakan media pembelajaran yang sesuai dengan materi sehingga mendukung proses pembelajaran pengenalan sains dengan baik. Media pembelajaran adalah media atau alat yang menjadi perantara dalam menyampaikan pembelajaran pada anak usia dini karena anak usia dini tidak bisa lepas dari media pembelajaran namun perinsipnya alat yang digunakan sebagai media pembelajaran tersebut harus mampu menstimulasi semua aspek perkembangan anak dan mampu mengatasi rasa bosan pada anak sehingga pembelajaran berjalan dengan efektif. Sehingga sangat penting adanya media dalam sebuah pembelajaran. Ada beberapa media yang digunakan oleh guru dan media itu digunakan sesuai dengan materi tema yang akan disampaikan jika tema yang didapat memungkinkan guru bisa membawa seperti: a. Media visual yang digunakan guru dalam pengenalan sains adalah dengan menggukan media realia atau berupa media nyata seperti ibu guru membawa buah jeruk sehingga anak dapat mengenal secara langsung seperti apa buah jeruk tersebut. Hal ini sejalan dengan yang dikemukaakan oleh badru dkk tentang media visual yaitu media yang dapat digunakan untuk menyampaikan pesan/informasi melalui penglihatan pemirsa atau media yang 


\begin{tabular}{|c|c|c|}
\hline \multicolumn{3}{|c|}{ Jurnal Warna : Jurnal Pendidikan Dan Pembelajaran Anak Usia dini. } \\
& Maret 2020. Vol 05. No. 01 \\
\hline Received: Februari 2020 & Accepted: Februari 2020 & Published: Maret 2020 \\
\hline & Article DOI: $10.24903 / j w . v 5 i 2.421$ \\
\hline
\end{tabular}

hanya dapat dilihat. Salah satu media yang digunakan seperti media realia, guru menggunakan media realia/nyata sesuai dengan penjelasan tentang media realia yaitu media ini merupakan benda yang sesumgguhnya sehingga dalam pengenalan sains media visual ini merupakan media yang baik digunakan (Badru Zaman, Asep Hery Hermawan, dkk, 2012:4.18-4.20). b. Media audio visual merupakan media yang digunakan guru dalam pengenalan sains dengan menggunakan media audio visual anak tidak hanya dapat melihat gambar tetapi juga dapat mendengar seperti dalam mengenalkan subtema binatang gajah. alat yang digunakan dalam pengenalan sains untuk media audio visual adalah leptop dan speacker. Hal ini sejalan dengan yang dikemukaakan oleh badru dkk tentang media audio visual merupakan kombinasi dari media audio dan media visual atau bisa disebut media pandang-dengar (Badru Zaman, Asep Hery Hermawan, dkk, 2012:4.21-4.24).

3. Penilaian Pengenalan Sains di PAUD

Terpadu Shabwa Amanah Landasan Ulin Utara Kec. Liang Anggang Kota Banjarbaru

Terakhir adalah penilaian kepada anak, sehingga kegiatan pembelajaran Pengenalan Sains Pada Anak Usia Dini di PAUD Terpadu Shabwa Amanah Landasan Ulin Utara Kec. Liang Anggang
Kota Banjarbaru menjadi terarah. Penilaian yang digunakan oleh guru dalam pembelajaran sains ada beberapa seperti a. Observasi /Pengamatan penilaian ini merupkan penilaian untuk mengetahui tahap perkembangan anak, jadi saat anak sedang melakukan kegiatan bermain disanalah guru pengenalan sains dapat mengamati sejauh mana perkembangan yang didapat anak. Dengan pengamatan juga guru dapat melihat bagaimana sikap dan perilaku anak hal ini sejalan dengan yang dikemukakan oleh Anik Lestariningrum tentang penilaian observasi/ pengamatan yaitu Cara pengumpulan data/informasi melalui pengamatan langsung maupun tidak langsung terhadap sikap dan perilaku anak, observasi dilakukan selama kegiatan pembelajaran berlangsung dengan menggunakan lembar observasi, catatan menyeluruh atau jurnal dan rubrik (Anik Lestariningrum, 2017:89). b. Percakapan selanjutnya penilaian yang digunaakan adalah percakapan karena dalam kegiatan pembelajaran pengenalan sains anak mendapatkan kosa kata baru, sehingga anak dapat mengingat kosakata yang telah dikenalkan sebelumnya ataupun kosa kata yang tidak pernah dikenalnya, seperti anak dapat menyebutkan apa saja warna pelangi semisal anak hanya tau dua warna tetapi saat penyampaian sub tema pelangi anak mengingat warna lain dan dapat 


\begin{tabular}{|c|c|c|}
\hline \multicolumn{3}{|c|}{ Jurnal Warna : Jurnal Pendidikan Dan Pembelajaran Anak Usia dini. } \\
& Maret 2020. Vol 05. No. 01 \\
\hline Received: Februari 2020 & Accepted: Februari 2020 & Published: Maret 2020 \\
\hline & Article DOI: $10.24903 / j w . v 5 i 2.421$ \\
\hline
\end{tabular}

menyebutkannya maka disana kosa kata dan aspek perkembangan bahasa anak berkembang. Hal ini sejalan dengan dikemukakan oleh Anik Lestariningrum tentang pecakapan. Percakapan merupakan penilain yang dilakukan melalui bercakap-cakap antara anak dan pendidik baik dalam kelas atau luar kelas, penilaian ini digunakan pada saat kegiatan terpimpin atau bebas. (Anik Lestariningrum, 2017:99). c. Penugasan dalam pembelajaran pengenalan sains anak diberikan kesempatan bermain apapun hanya saja anak harus menyelesaikan 1 kegiatan terlebih dahulu baru ditugaskan lagi kepermainan selanjutnya dan saat anak melakukan kegiatan bermain guru akan melakukan penilaian tentang apa saja tugas atau kegiatan yang sudah dikerjakan anak hari ini. Hal ini sejalan dengan yang dikemukakan oleh Anik Lestariningrum tentang penugasan. Penugasan merupakan penilain berupa pemberian tugas yang akan dikerjakan anak dalam waktu tertentu baik secara individu maupun kelompok baik secara mandiri atau didampingi (Anik Lestariningrum, 2017:100). e. Hasil Karya adalah salah satu penilaian yang digunakan guru, karena saat anak melakukan kegiatan seperti mewarna pelangi, kolase buah jeruk dan menggambar sampai selesai maka hasil dari kegiatan yang anak kerjakan tersebut disebut dengan hasil karya anak dan hasil tersebut kemudian dapat dikumpulkan kepada guru, sama halnya yang dikemukakan oleh Anik Lestariningrum tentang hasil karya yang mana hasil karya adalah hasil kerja anakanak didik setelah melakukan suatu aktivitas (Anik Lestariningrum, 2017:101).

\section{PENUTUP}

\section{Kesimpulan}

Berdasarkan hasil penelitian tentang Pengenalan Sains Pada Anak Usia Dini di PAUD Terpadu Shabwa Amanah Landasan Ulin Utara Kec. Liang Anggang Kota Banjarbaru dapat disimpulkan bahwa:

Pengenalan Sains Pada Anak Usia Dini di PAUD Terpadu Shabwa Amanah Landasan Ulin Utara Kec. Liang Anggang Kota Banjarbaru mengenalkan konsep sains berupa pencampuran air dengan sabun yang menjadi gelembung-gelembung kecil, tenggelam dan mengapung, perubahan warna dan penyerapan air dengan menggunakan metode, media dan penilaian berupa: 1.) Metode yang digunakan yaitu metode demontrasi, metode eksperimen, metode bercakap-cakap (tanya jawab), metode pemberian tugas, metode bermain, dan metode bernyanyi. Selanjutnya media yang digunakan 2.) Media visual berupa media realia dan media audio visual. 3.) Penilaian yang diberikan berupa memberikan 


\begin{tabular}{|c|c|c|}
\hline \multicolumn{3}{|c|}{ Jurnal Warna : Jurnal Pendidikan Dan Pembelajaran Anak Usia dini. } \\
& Maret 2020. Vol 05. No. 01 \\
\hline Received: Februari 2020 & Accepted: Februari 2020 & Published: Maret 2020 \\
\hline & Article DOI: $10.24903 / j w . v 5 i 2.421$ \\
\hline
\end{tabular}

penugasan permainan pada anak yang nanti akan dicatat apa saja permainan yang dimainkan anak, penilaian selanjutrnya penilaian observasi atau melalui pengamatan, penilaian melalui percakapan, serta hasil karya.

\section{Saran}

Berdasarkan analisis di atas, maka peneliti memberikan saran kepada pihak yang berkepentingan yang sekiranya dapat dijadikan bahan pertimbangan dalam pengenalan sains pada anak usia dini di PAUD Terpadu Shabwa Amanah Landasan Ulin Utara Kec. Liang Anggang Kota Banjarbaru:

1. Kepada kepala sekolah sudah memberikan fasilitas yang baik terhadap kegiatan pengenalan sains dengan menyediakan segala sarana dan prasarana yang menunjang proses kegiatan pengenalan sains, sehingga untuk selanjutnya agar kepala sekolah tetap mempertahankan dan mungkin lebih meningkatkan lagi sarana dan prasarana dalam kegiatan pembelajaran pengenalan sains pada anak usia dini.

2. Kepada guru dalam pengenalan sains sudah mengenalkan dengan bervariasi, mungkin untuk selanjutnya guru dapat memperbaharui lagi metode dan media yang terbaru agar dalam kegiatan pengenalan sains tetap bervariasi sehingga membuat anak menjadi aktif terus menerus dalam mengikuti kegiatan pengenalan sains.

\section{DAFTAR PUSTAKA}

Budiyanti,. (2007). Pembelajaran Pengenalan Sains Sederhana Pada Topik Gravitasi Dengan Pendekatan Bermain Sambil Belajar Untuk Melatih Kemampuang Berpikir Siswa, Skripsi; Universitas Negri Semarang. [1]

Dimyati, Johni,. (2013). Metodelogi Pendidikan \& Aplikasinya Pada Pendidikan Anak Usia Dini (PAUD), Jakarta: Kencana. [2]

Ekonomi, M.F Sri,. (2007). Bahasa Inggris Untuk Anak Usia Dini, Banjarmasin-Jogjakarta: PBS FKIP Unlam-Ircisod. [3]

H. Idris, Meiti,. (2015). Strategi Pembelajaran Yang Menyenangkan, Jakarta Timur: Pt. Luxima Metro Media [4]

Lestariningrum, Anik,. (2017). Perencana Pembelajaran Anak Usia Dini, Watudandang Prambon Ngajuk: Cv. Adjie Media Nusantara. [5]

Putra, Nusa \& Nini Dwilestari,. (2013). Penelitian Kualitatif PAUD, Jakarta: Rajawali Pers. [6]

Sari, Nita Ratna,. (2015). Metode Eksperimen Berpengaruh Terhadap Kemampuan Sains Anak, Skripsi; Universitas Muhammadiah Surakarta. [7]

Siregar, Irma Yanti,. (2019). Penerapan Metode Eksperimen Dalam Pembelajaran Sains Untuk Anak Usia Dini Di Tk Siti Al-Hasan Kecamatan Batang Kuis Kabupaten Deli Serdang, Skripsi; Universitas Islam Negeri Sumatera Utara Medan. [8]

Susilowati, Neni,. (2016). Pengenalan Sains Melewati Percobaan Sederhana Dalam Pembelajaran Sains Pada Anak Kelompok $B$, Skripsi; Universitas Negeri Yogyakarta. [9]

Zaman, Badru,. Hermawan, Asep Hery, dkk, (2012). Media dan Sumber Belajar TK, Tengerang Selatan: Universitas Terbuka. [10] 